\title{
'Grasslands Roa' tall fescue seed production: research and practice
}

\author{
M.D. HARE', M.P. ROLSTON'. W.J.ARCHIE ${ }^{2}$, and J. McKENZIE ${ }^{3}$ \\ 'DSIR Grásslands, Private Bag, Palmerston North \\ ${ }^{2}$ DSIR Grasslands, Private Bag, Christchurch
}

${ }^{3}$ Agricom NZ Ltd, Ashburton

\begin{abstract}
Seed yields of 'Grasslands Roa' tall fescue (Festuca arundinacea Schreb.) have ranged from 200 to $1450 \mathrm{~kg} / \mathrm{ha}$, with some handharvested research plots producing $3600 \mathrm{~kg} / \mathrm{ha}$. Better management has increased seed yields, i.e., growing seed crops on deep, moistureretentive soils, lenient autumn and winter grazing, closing by late winter (mid July), applying $120 \mathrm{~kg} \mathrm{~N} / \mathrm{ha}$ and careful harvesting techniques. Time of sowing, undersowing with barley crops, weed control and plant growth regulators are also discussed.
\end{abstract}

K eywords tall fescue, seed production, Festuca arundinacea, 'Grasslands Roa'

\section{Introduction}

'Grasslands Roa' tall fescue (Festuca audrace Schreb.) was released in 1980 (Anderson 1982) as a robust perennial grass which has high summer productivity and drought tolerance. Seed yields initially averaged $600 \mathrm{~kg} / \mathrm{ha}$ at -research stations_and farm yields ranged from 250 to $400 \mathrm{~kg} / \mathrm{ha}$. However, in the last 2 years, farm yields have reached 1000 $\mathrm{kg} / \mathrm{ha}$ and small research plots have produced over $3000 \mathrm{~kg} / \mathrm{ha}$ (hand harvested), The research results that have led to these improvements in seed yield are presented in this paper.

\section{Establishment}

Experience has shown that deep, moderately drained, fertile, moisture-retentive soils should be chosen for tall fescue seed production. On lighter, drier and infertile-coils, seed yields are often no more than $100 \mathrm{~kg} / \mathrm{ha}$, even though cocksfoot and ryegrass may produce good seed yields on these sites.

Late spring-early summer frosts can damage tall fescue inflorescences during emergence from the tiller and at anthesis (Youngberg \& Wheaton 1979). Very hot or dry conditions at the time of seed maturation can also reduce seed yields. These sites should be avoided.

The highest seed yields in New Zealand (3685 $\mathrm{kg} / \mathrm{ha}$, hand harvested; $1450 \mathrm{~kg} / \mathrm{ha}$ combine harvested) have come from the Manawatu where soil has remained moist up until seed harvest and the summers have been mild.

Paddocks with a history of ryegrass seed crops or hay making must be avoided as ryegrass seed cannot be dressed out of tall fescue seed. Hay and straw must not be fed out on seed crop paddocks and sheep grazing must be managed to ensure no ryegrass contamination enters the paddock.

Time of sowing

Tall fescue cultivars are slow to establish, Roa being no exception (Brock et al. 1982). Slow establishment means that tall fescue seed crops sown in the autumn do not reach maximum seed yields until the second summer after seeding (Youngberg \& Wheaton 1979), because the autumn sown plants have not grown large enough or tillered adequately to undergo the autumn-early winter vernalisation required for maximum seed production (Bean 1970).

For seed production tall fescue has been mainly spring or early summer sown for maximumi seed yields in the first year. Recent work at Lincoln and in the Manawatu investigated monthly sowing of Roa from October until April (Table 1). Seed yields after spring-sowing-were significantly-greater-than-those after autumn sowing. However, the early autumn sowings in the Manawatu still produced a good seed crop. Tall fescue can therefore be autumn sown, after arable crops such as peas, in- regions with mild, warm winters. Spring-early summer sowings are still advised for regions with cold winters such as Canterbury and Otago.

Table 1 Effect of time sowing on Roa tall fescue seed yields in the Manawatu and at Lincoln (1990).

\begin{tabular}{|c|c|c|}
\hline \multirow[t]{2}{*}{ Sowing first week of: } & \multicolumn{2}{|c|}{ Seed yields kg/ha' } \\
\hline & Manawatu & Lincoln \\
\hline October & 3380 & 1450 \\
\hline November & 3690 & 1410 \\
\hline December & 3020 & 1630 \\
\hline January & 3180 & 1110 \\
\hline February & 2910 & 850 \\
\hline March & 1490 & 570 \\
\hline April & 940 & 170 \\
\hline May & 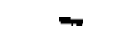 & 0 \\
\hline LSD $5 \%$ & 670 & 675 \\
\hline
\end{tabular}

$14 \%$ seed moisture and hand harvested 


\section{Method of sowing}

Tall fescue crops are usually sown as pure stands, but if the crop is spring sown, there is a 15-month interval before the first seed crop can be taken. Recent Manawatu trials have found that Roa can be successfully established under barley (Table 2) or linseed in Canterbury without significant effects on Roa seed yields. Roa can either be drilled across the barley in $30 \mathrm{~cm}$ rows (Table 2), or every alternate drill sown with either barley or Roa tall fescue. Undersowing cereals, linseed or dry pea crops with Roa tall fescue is a viable practice.

Table 2 Effect of undersowing on Roa tall fescue and Triumph barley yields in the Manawatu.

\begin{tabular}{|c|c|c|c|}
\hline Treatments & $\begin{array}{c}\text { Barley row } \\
\text { spacing/seeding } \\
\text { rate }\end{array}$ & $\begin{array}{l}\text { Barley } \\
\text { grain } \\
\text { yield' } \\
(\mathrm{t} / \mathrm{ha}) \\
\end{array}$ & $\begin{array}{l}\text { Roa } \\
\text { seed } \\
\text { yield' } \\
\text { (t/ha) } \\
\end{array}$ \\
\hline 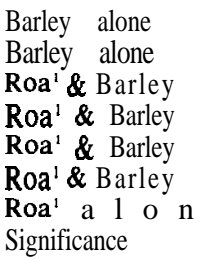 & $\begin{array}{l}15 \mathrm{~cm} / 150 \mathrm{~kg} / \mathrm{ha} \\
15 \mathrm{~cm} / 75 \mathrm{~kg} / \mathrm{ha} \\
15 \mathrm{~cm} / 37.5 \mathrm{~kg} / \mathrm{ha} \\
13 \mathrm{~cm} / 75 \mathrm{~kg} / \mathrm{ha} \\
30 \mathrm{~cm} / 37.5 \mathrm{~kg} / \mathrm{ha} \\
30 \mathrm{~cm} / 75 \mathrm{~kg} / \mathrm{ha} \\
\mathrm{e}\end{array}$ & $\begin{array}{c}4.36 \\
4.44 \\
2.76 \\
3.13 \\
2.61 \\
4.11 \\
\mathrm{P}<\overline{0.02}\end{array}$ & $\begin{array}{l}\overline{-} \\
2780 \\
2030 \\
2710 \\
2200 \\
2650 \\
\text { n.s. }\end{array}$ \\
\hline
\end{tabular}

${ }^{1}$ Roa $7 \mathrm{~kg} / \mathrm{ha}$ seeding rate cross drilled at $30 \mathrm{~cm}$ row spacing

$214 \%$ seed moisture and hand harvested.

Drilling seed is preferred to broadcast sowmg because of the more uniform stand which results from placing the seed at the right depth $(1-2 \mathrm{~cm})$ and covering the seed by chain harrowing or rolling, thereby aiding germination and emergence. Trials in Southland found that sowing 2.5 to $5 \mathrm{~kg} / \mathrm{ha}$ of seed in $30 \mathrm{~cm}$ row spacings gave better seed yields than 60 $\mathrm{cm}$ rows (Hickey 1991). However, at Lincoln $15 \mathrm{~cm}$ row spacings have given slightly higher seed yields than $30 \mathrm{~cm}$ row spacings over two years $(525 \mathrm{~kg} / \mathrm{ha}$ and $474 \mathrm{~kg} / \mathrm{ha}$ respectively).

To maintain Roa tall fescue seed yields over the six harvest seasons allowed in seed certification, sowing in $30 \mathrm{~cm}$ rows may prevent the stand becoming 'sodbound'. The seed yield on densely sown tall fescue stands in the US declines at a faster rate than that of wider row spaced stands, because of excessive competition for space by new tillers (Youngberg \& Wheaton 1979)

\section{Management from establishment to harvest}

Weed control in first year stands

Broadleaf weeds can be controlled with 2,4-D $(1.2 \mathrm{~kg}$ ai/ha), dicamba ( $0.2 \mathrm{~kg}$ ai/ha), bromoxynil/ioxynil (0.4 kg ai/ha, Combine), MCPA (1.2 kg ai/ha) or methabenzthiazuron (1 $\mathrm{kg}$ ai/ha, Tribunil DF). Spraying should not take place until 4-5 weeks after emergence. Grass weeds are very difficult to control but ethofumesate $(1.5-2.0 \mathrm{~kg}$ ai/ha) will control many annual grasses such as Poa annua and seedlings of Bromus willdenowii. Difenzoquat $(0.9 \mathrm{~kg}$ ai/ha, Avenge 640 A) will control wild oats (Avena fatua). The above rates are the same for established stands.

\section{Weed control in established stands}

Annual grasses and broadleaf weeds can be controlled by autumn or winter applications of atrazine, simazine, chlorpropham or diuron when the soil is moist. In four trials in the Manawatu tall fescue showed good tolerance to atrazine $(2.0-4.5 \mathrm{~kg}$ ai/ha), simazine (2.0-4.0 kg ai/ha), diuron (2.0-6.0 $\mathrm{kg} \mathrm{ai} / \mathrm{ha}$ ) and metribuzin (1.0-1.5 kg ai/ha) (Rolston \& Archie 1990)

Atrazine will give some control of seedling ryegrass, as ryegrass is shallower rooted than tall fescue, and therefore more susceptible to soil active herbicides. However, to control ryegrass successfully spot spraying with glyphosate is necessary.

Atrazine will kill tall fescue seedlings growing from fallen seed and prevent the stand becoming too dense. In Canterbury, crop damage can occur at atrazine rates of $1.5 \mathrm{~kg}$ ai/ha (Rolston \& Archie 1990). This damage is possibly associated with a lack of rain to wash herbicides off the leaves in to the soil.

\section{Fertiliser}

In first-year crops, $80 \mathrm{~kg} \mathrm{~N} / \mathrm{ha}$ was sufficient for maximum seed production (Hare \& Rolston 1990), but in older crops (sixth and seventh seed harvest) up to $120 \mathrm{~kg} \mathrm{~N} / \mathrm{ha}$ had to be applied for maximum seed yields (Table 3). Even though there was no difference between a split autumn/spring $\mathrm{N}$ application and applying all the $\mathrm{N}$ in the spring, we still prefer the split application. Crops with no autumn $\mathrm{N}$ can look quite yellow by mid-winter.

Spring nitrogen applied before spring growth starts can cause excessive vegetative growth and lodging (Youngberg \& Wheaton 1979). Hare \& Rolston (1990) found that when spring nitrogen was applied at stem elongation, seed yields $(1034 \mathrm{~kg} / \mathrm{ha})$ were substantially higher than when spring nitrogen was applied after stem elongation (682 kg/ha).

On the basis of soil test results, phosphorus and potassium applications may have to be applied in

Table 3 Effect of autumn (A) and spring (S) nitrogen rates on Roa tall fescue seed vields, (kg/ha) ${ }^{1}$ (after Hare \& Rolston 1990).

\begin{tabular}{|c|c|c|}
\hline $\begin{array}{l}\text { Nitrogen } \\
\text { kg/ha }\end{array}$ & $\begin{array}{c}\text { 6th Harvest } \\
\text { vear }\end{array}$ & $\begin{array}{c}\text { 7th Harvest } \\
\text { vear }\end{array}$ \\
\hline 0 & 510 & 620 \\
\hline $40 \mathrm{~A}$ & 520 & 810 \\
\hline $40 A+40 s$ & 800 & 1040 \\
\hline $40 A+80 S$ & 850 & 1320 \\
\hline $40 \mathrm{~S}$ & 650 & 870 \\
\hline $80 \mathrm{~S}$ & 740 & 940 \\
\hline $120 \mathrm{~s}$ & 860 & 1220 \\
\hline LSD $5 \%$ & 250 & 270 \\
\hline
\end{tabular}

1 14\% seed moisture and hand harvested 
second year and subsequent crops. If soil $\mathrm{pH}$ falls below 5.5, lime should also be applied (Rolston et al. 1985).

\section{Plant growtb regulators (PGRs)}

Seed yields of tall fescue have increased by 300 to 350 $\mathrm{kg} / \mathrm{ha}$ after growth regulator applications (paclobutrazol and flurprimidol at $2 \mathrm{~kg}$ ai/ha) (Hare, Rolston \& Hampton, unpub. data). These yield responses have been on heavy moisture retentive soils in the Manawatu when PGRs were applied at spikelet initiation (2 September). On light soils and with late spring applications no PGR responses were recorded (Archie, unpub. data).

\section{Grazing and closing date}

After spring and early summer establishment, tall fescue can be leniently grazed to $5-10 \mathrm{~cm}$ above ground level in the autumn and winter. Tillers initiated in the autumn and early winter produce the most seed, so care must be taken at these times not to graze close to ground level. However, excessive foliage must be removed to allow light into the developing tillers.

Grazing or defoliation must be stopped by late winter; later closings in the spring have substantially reduced seed yields (Brown et al. 1988).

Tall fescue seed crops in the Pacific Northwest US are cut, not grazed, and produce seed yields 2.5 times the national US average (Youngberg \& Wheaton 1979). In trials in the Manawatu the highest handharvested yields of over $3000 \mathrm{~kg} / \mathrm{ha}$ (Table 1) were from plots that were never grazed; they were cut with rotary mowers to $5-10 \mathrm{~cm}$ above ground level in April and early July. High combine harvested yields, 1450 $\mathrm{kg} / \mathrm{ha}$, have also been produced when cattle have leniently grazed the crop during autumn and winter up until closing in mid-July.

\section{Irrigation}

Although tall fescue is a drought-tolerant-plant, -it is highly susceptible to moisture stress during anthesis and seed development. Premature ripening which produces small, low germinating shrivelled seed can occur. Shedding will also occur. To prevent significant reductions in seed yield in hot, dry, northwest conditions in Canterbury, the return period for irrigation may only be a week during anthesis and seed development.

\section{Harvesting}

\section{Method of harvesting}

The seed of tall fescue sheds easily when it is ripe. Delays in harvest caused by rain and machinery breakdowns or high winds can easily reduce seed yields by $50 \%$ or more (Youngberg \& Wheaton 1979). Extreme care and skill are required during mowing and harvesting to prevent further losses.

Roa tall fescue seed can be direct headed, cut with a mower and combined, or windrowed and combined.
Direct-heading is a feasible method if the crop has not lodged, the area is not too large (ie, can be harvested in 1-2 days), and seed drying facilities are available. Direct heading should begin when the seed moisture content (SMC) is between 45 and $50 \%$. Direct-headed seed must not be placed in large bins, as subsequent heating will cause low germination and losses in seed vigour. The seed must be dried immediately on the day of harvest, firstly with ambient air to a seed moisture content below 18-20\% and then, secondly, with warm air to below $14 \%$ SMC. To avoid seed damage, the warm air must not exceed $35{ }^{\circ} \mathrm{C}$ at the flue entrance.

Mowing and curing the seed in the cut swath is the best harvest method for large areas, where winds are strong and where lodging occurs. Tall fescue can be mown when the SMC is about $48 \%$. The cut or windrowed swath will take several days to dry down to $20-14 \%$ SMC before seed harvesting. Growers who do not have drying facilities must take particular care that the seed is below 14\% SMC at harvest.

\section{Seed storage}

Tall fescue seed is very senstitive to moisture and temperature and must be stored under low humidity and cool conditions. Drying to below 14\% SMC and storing in standard warehouse conditions should maintain tall fescue viability for 24 months. For long term storage, cool, low humidity conditions have to be used.

\section{Post-harvest management}

Management immediately after harvest is extremely important for seed production in the following season, because reproductive tillers for the next harvest are initiated in the autumn and early winter, and accumulated straw, debris or stubble can seriously. impair tiller-development, thereby lowerīing seed yields (Youngberg \& Wheaton 1979).

Straw should be removed immediately after harvest by baling or burning. Baled tall fescue straw is very leafy and palatable (often more so than ryegrass straw) and can provide additional cash income if sold. After the straw is removed the stubble must be hard grazed.

In the US, burning the stubble and straw as soon as possible after harvest has increased tall fescue seed yields by more than $20 \%$ when compared with baling and removing only the straw (Youngberg 1980). Burning in New Zealand is generally considered only if the straw value is nil. The straw must be spread evenly over the field as burning windrows can seriously damage tall fescue plants. If burning is delayed until after the initiation of autumn tillers, seed yields can be seriously reduced. In ageing seed crops, low germinations (60\%) have been a problem, possibly due to blind seed (Gloetinia temulenta). Burning will control blind seed and also ergot (Claviceps purpurea) (Hardison 1976). 
Gapping with glyphosate has been successful in Canterbury. Roa seed crops have been sown in $15 \mathrm{~cm}$ rows and then once established, handsprayed at right angles (spray $10 \mathrm{~cm}$, leave $15 \mathrm{~cm}$ ). This practice could also be done in older crops if they become clumpy or sod-bound. Gapping prevents too much inter-tiller and inter-plant competition from taking place. Mechanical gapping could also be done in the autumn.

\section{Summary}

By following the management practices in this paper, seed yields of over $1000 \mathrm{~kg} / \mathrm{ha}$ (machine harvested) can readily be achieved. We use the same management to produce seed of 'Grasslands Garland' amenity tall fescue.

\section{REFERENCES}

Anderson, L.B. 1982. 'Grasslands Roa' tall fescue (Festuca arundinacea Schreb.) $N Z$ journal of experimental agriculture 10: 269-273.

Bean, E.W. 1970. Short-day and low-temperature control of floral induction in Festuca. Annals of botany 34: 57.66.

Brown, K.R.; Ralston, M.P.; Hare, M.D.: Archie, W.J. 1988. Time of closing for 'Grasslands Roa' tall fescue seed crops. NZ journal of agricultural research 31 383.388.
Brock, J.L.; Anderson, L.B.; Lancashire, J.A. 1982. 'Grasslands Roa' tall fescue: seedling growth and establishment. NZ journal of experimental agriculture 10: 285-289.

Hardison, J.R. 1976. Fire and flame for plant disease control. Annual review of phytopathology 14: 355-379.

Hare, M.D.; Rolston, M.P. 1990. Nitrogen effects on tall fescue seed production. Journal of applied seed product+ 8: in press.

Hickey, M.J. 1991. Seed Production of 'Grasslands Roa' tall fescue in Southland. Proceedings of the $\mathrm{New}$ Zealand Grassland Association 52: this issue.

Rolston, M.P.; Archie, W.J. 1990. Herbicide tolerance of established tall fescue and phalaris seed crops. Proceedings of the 43rd New Zealand Weed and Pest Control Conference: 134-137.

Rolston, M.P.; Brown,. K.R.; Hare, M.D.; Young, K.A. 1985. pp. 15-22. In Hare, M.D.; Brock, J.L., (editors). Producing Herbage Seeds. Grassland Research and Practice Series No. 2. New Zealand Grassland Association, Palmerston North.

Youngberg, H. 1980. Techniques of seed production in Oregon. pp. 203-213. In Hebblethwaite, P.D. (editor) Seed production. 28th Easter School in Agricultural Science. University of Nottingham, 1978. Longdon: Butterworths.

Youngberg, H.; Wheaton, H.N. 1979. Seed production., pp: 141-153. In Buckner, R.C.; Bush, L.P. (editors). Tall fescue. Agronomy series 20. ASA-CSSA-SSSA. Madison, USA. 